\title{
Polyamine-enhanced casein kinase II in mouse pancreatic islets
}

\author{
P.Thams, K. Capito and C.J.Hedeskov \\ Department of Biochemistry A, University of Copenhagen, Copenhagen, Denmark
}

\begin{abstract}
Summary. The occurrence of polyamine-stimulated protein kinase (casein kinase II) in cytosol of mouse pancreatic islets was investigated. Islet protein phosphorylation was enhanced by spermidine, spermine, lysine-rich histone and polylysine; the major endogenous substrates in the cytosol were three proteins of $\mathrm{Mr} 50000,55000$ and 100000 . Cadaverine and putrescine were without effects. A Mr 100000 protein is a major substrate for $\mathrm{Ca}^{2+}$-calmodulin-dependent protein kinase, and Mr 50000 and 55000 proteins are substrates for cyclic adenosine 3',5'-cyclic monophosphate (AMP) dependent protein kinase in mouse islets. However, neither cyclic-AMP-dependent protein kinase inhibitor nor trifluoperazine inhibited polyamine-enhanced protein phosphorylation. Both basal and
\end{abstract}

polyamine-enhanced protein phosphorylation patterns were identical when either $\left[\gamma_{-}{ }^{32} \mathrm{P}\right]$ adenosine 5 '-triphosphate (ATP) or $\left[\gamma^{-{ }^{32}} \mathrm{P}\right]$ guanosine $5^{\prime}$-triphosphate (GTP) was used as phosphate donors, indicative of the presence of a polyaminestimulated casein kinase II in pancreatic islets. It is suggested that polyamines and polyamine-enhanced casein kinase II activity may have an important role in regulation of protein phosphorylation in pancreatic islets.

Key words: casein kinase II, calmodulin-dependent protein kinase, cyclic AMP-dependent protein kinase, polyamines, pancreatic islets.
It is now well recognized that the phosphorylation/dephosphorylation of proteins is a very important process in the regulation of insulin secretion from pancreatic islets. Both cyclic AMP-dependent, $\mathrm{Ca}^{2+}$-calmodulin-dependent and $\mathrm{Ca}^{2+}$-phospholipid-dependent (protein kinase C) protein phosphorylation have been identified in pancreatic islets [1-3]. It is currently believed that insulin secretion from pancreatic islets is regulated by these three convergent but independent phosphorylation systems $[4,5]$.

The role of polyamines in protein phosphorylation and stimulus-secretion-coupling is receiving increasing attention. Thus, polyamines have been shown to stimulate cyclic nucleotide-independent protein kinases (casein kinase II) [6-8], to be without effect on cyclic nucleotide-dependent protein kinases, or to inhibit $\mathrm{Ca}^{2+}$-calmodulin-dependent myosin light chain kinase and protein kinase C [9]. We have recently identified high concentrations of the polyamines putrescine, spermidine and spermine in mouse islets, and found evidence to suggest that polyamines bound to phospholipids in membranes may prevent binding and activation of protein kinase $\mathrm{C}$ and that $\mathrm{Ca}^{2+}$-influx may function by displacing membrane-bound polyamines [5].

The aim of the present study was to investigate the presence of polyamine-enhanced casein kinase II activity in mouse islets.

\section{Materials and methods}

\section{Materials}

Crude bacterial collagenase and cyclic AMP were obtained from Boehringer, Mannheim, FRG. 2-((2-hydroxy-1-1,-bis-(hydroxymethyl)-ethyl)amino)-ethanesulphonic acid (Tes), ethylene glycol bis ( $\beta$ aminoethyl ether)- $\mathbf{N}, \mathbf{N}, \mathrm{N}^{\prime}, \mathrm{N}^{\prime}$,-tetraacetic acid (EGTA), benzamidine, dithiothreitol, lysine-rich histone (III-S, histone H1, mol.wt. 10000), cadaverine, putrescine, spermidine, spermine, polylysine (mol. wt. 3500), cyclic AMP-dependent protein kinase inhibitor, GTP and ATP were purchased from Sigma Chemical Co., St. Louis, Mo, USA. Trifluoperazine was given by Rhône-Poulenc, Pharma Norden A/S, Copenhagen, Denmark. $\left[\gamma_{-}{ }^{32} \mathrm{P}\right]$ ATP (sp. radioactivity $3000 \mathrm{Ci} / \mathrm{mmol}$ ) and $\left[\gamma-{ }^{32} \mathrm{P}\right] \mathrm{GTP}$ (sp. radioactivity $10 \mathrm{Ci} / \mathrm{mmol}$ ) were from the Radiochemical Centre, Amersham, Bucks, UK.

\section{Methods}

Preparation of islets. Islets were prepared by using collagenase digestion [10] of the pancreases of male albino mice (approximately $26 \mathrm{~g}$ body weight) fed ad libitum on a standard laboratory diet.

Preparation of islet cytosol. A group of 500 islets was collected in $100 \mu \mathrm{l}$ of Tes buffer $(25 \mathrm{mmol} / 1$, $\mathrm{pH} 6.90)$ containing $\mathrm{MgCl}_{2}(5 \mathrm{mmol} /$ 1), EGTA $(1 \mathrm{mmol} / 1)$, dithiothreitol $(0.1 \mathrm{mmol} / \mathrm{l})$ and benzamidine $(10 \mathrm{mmol} / \mathrm{l})$. A homogenate was prepared by sonication $(10 \mathrm{~s}, 40 \mathrm{~W})$. For the preparation of a soluble fraction, the homogenate was centrifuged for $20 \mathrm{~min}$ at $27000 \mathrm{~g}$ at $4^{\circ} \mathrm{C}$. The supernatant was frozen in liquid $\mathrm{N}_{2}$ and stored at $-80^{\circ} \mathrm{C}$ until the next day. 


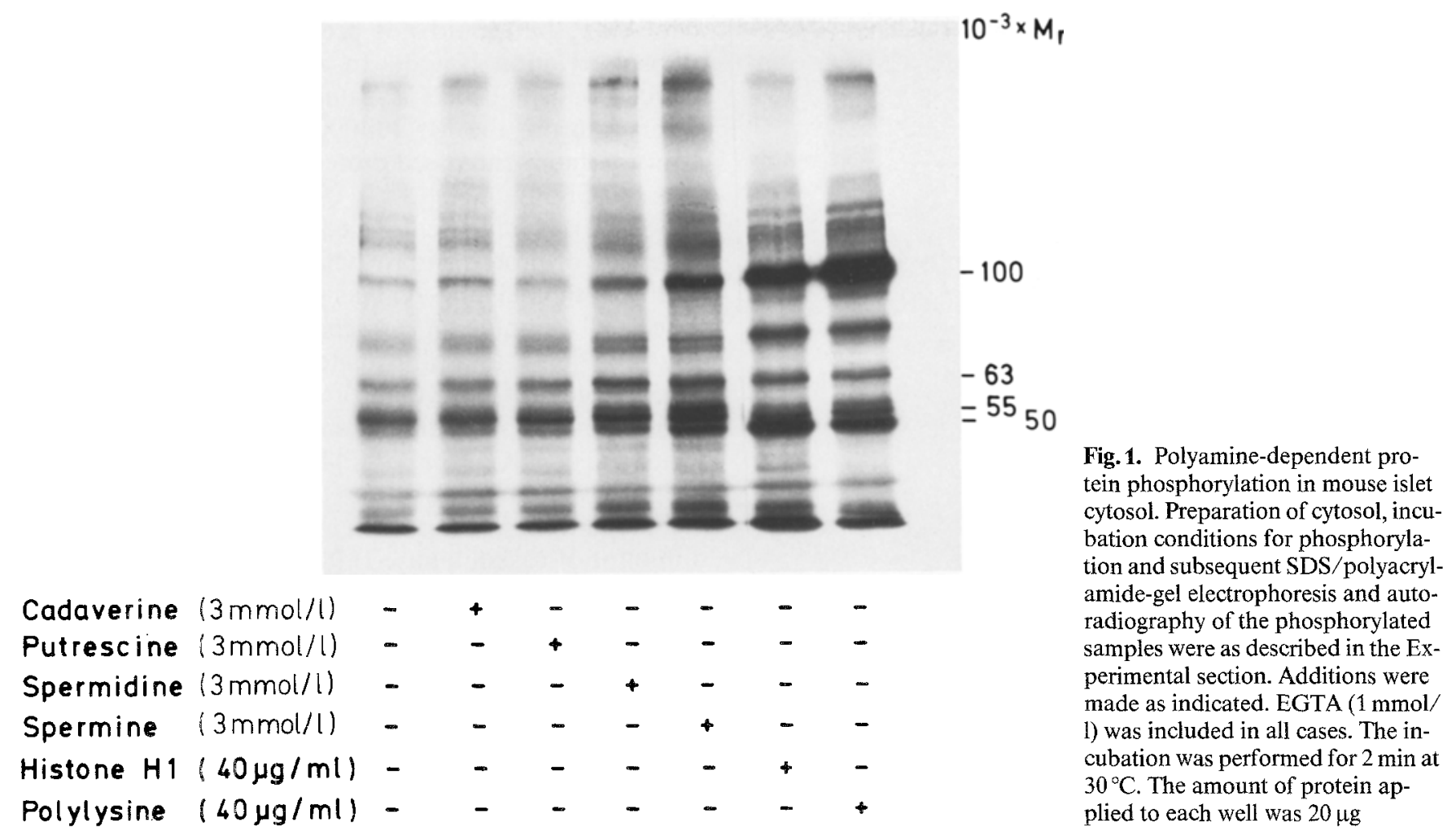

Phosphorylation assay. Samples of islet cytosol (corresponding to 50 islets) were preincubated for $2 \mathrm{~min}$ in a reaction mixture (final volume $5 \mu \mathrm{l})$ containing Tes buffer $(25 \mathrm{mmol} / 1,50 \mathrm{pH} 6.90), \mathrm{MgCl}_{2}(5 \mathrm{mmol} /$ 1), EGTA $(1 \mathrm{mmol} / \mathrm{l})$, dithiothreitol $(0.1 \mathrm{mmol} / \mathrm{l})$ and benzamidine $(10 \mathrm{mmol} / \mathrm{l})$, and further additions as indicated in the text and Figures. The reaction was started by addition of $\left[\gamma^{32} \mathrm{P}\right] \mathrm{ATP}$ or [ $\left.\gamma{ }^{32} \mathrm{P}\right]$ GTP $(4-12 \mathrm{Ci} / \mathrm{mmol}$, final concentration $10 \mu \mathrm{mol} / \mathrm{l})$. The reaction was carried out at $30^{\circ} \mathrm{C}$ for $2 \mathrm{~min}$ and terminated by addition of $50 \mu \mathrm{l}$ of a solution containing Tris/HCL $(40 \mathrm{mmol} / 1, \mathrm{pH} 7.80), 4 \%(\mathrm{w} /$ v) SDS, 4\% (v/v) 2-mercaptoethanol, $10 \%(\mathrm{v} / \mathrm{v})$ glycerol and $0.016 \%$ $(\mathrm{w} / \mathrm{v})$ Bromophenol Blue, and heating at $95^{\circ} \mathrm{C}$ for $3 \mathrm{~min}$. After cooling, the samples were left at room temperature overnight before electrophoresis on SDS/polyacrylamide gels.

SDS/polyacrylamide-gel electrophoresis and autoradiography. Samples $(35 \mu \mathrm{l}$ or $75 \mu \mathrm{l})$ were electrophoresed in SDS/polyacrylamide slab gels by a modification of the method of Laemmli [11]. The separation gel contained $7.5 \%(\mathrm{w} / \mathrm{v})$ acrylamide, Tris $/ \mathrm{HCl}(0.375 \mathrm{~mol} / 1$, pH 8.70$)$, and $0.1 \%(\mathrm{w} / \mathrm{v})$ SDS. The stacking gel contained $5 \%$ acrylamide, Tris $/ \mathrm{HCl}(0.127 \mathrm{~mol} / 1, \mathrm{pH} 7.80)$, and $0.1 \% \mathrm{SDS}$. The electrophoresis buffer was Tris $(0.025 \mathrm{~mol} / 1) /$ glycine $(0.192 \mathrm{~mol} / 1)$ buffer, $\mathrm{pH} 8.30$, containing $0.1 \%$ SDS. The electrophoresis was run at a constant current of $7.5 \mathrm{~mA}$ and $20 \mathrm{~mA}$ for the passage of proteins through the stacking and separating gel respectively. After staining with Coomassie Brilliant Blue, the gels were dried and then subjected to autoradiography with Kodak DEF X-ray film. Autoradiograms were scanned using a Kipp \& Zonen densitometer DD2.

$\mathrm{Mr}$ values of the phosphoproteins were estimated by using the following proteins, with the indicated $\mathrm{Mr}$ values as standards: myosin, 200000 ; $\beta$-galactosidase, 116250 ; phosphorylase $b, 92500$; bovine serum albumin, 66200 ; ovalbumin 45000 ; carbonic anhydrase, 31000 .

The autoradiograms shown are representative of at least three similar experiments.

\section{Results}

Phosphorylation and autoradiography of the proteins in islet cytosol revealed 4 proteins with $\mathrm{Mr}$ values of $50000,55000,63000$ and 100000 , which were phosphorylated on addition of spermidine and spermine (Fig.1). Cadaverine and putrescine were without effect. The phosphorylation of the $50000,55000,63000$ and 100000 proteins was also achieved on addition of $1 y$ sine-rich histone or polylysine, the 100000 protein being heavily phosphorylated in the presence of these agents.

Phosphorylation in the presence of cyclic AMP and $\mathrm{Ca}^{2+}$ revealed 2 substrate proteins with $\mathrm{Mr}$ values of 50000 and 55000 for cyclic AMP-dependent protein kinase and 1 substrate protein for $\mathrm{Ca}^{2+}$-calmodulin-dependent protein kinase with a $\mathrm{Mr}$ value of 100000 (Fig. 2). The phosphorylation of the Mr 100000 protein is mediated by endogenous calmodulin in the cytosol and is not further enhanced by addition of exogenous calmodulin [2]. These proteins may be identical to the 50000,55000 and 100000 proteins phosphorylated in the presence of spermine (Fig. 2). The spermine-enhanced phosphorylation of the $\mathrm{Mr} 63000$ protein was absent in several preparations of islet cytosol (Fig. 2).

To investigate the possibility that cyclic AMP-dependent and $\mathrm{Ca}^{2+}$-calmodulin-dependent protein $\mathrm{ki}$ nases were involved in polyamine-enhanced protein phosphorylation, the effects of cyclic AMP-dependent 


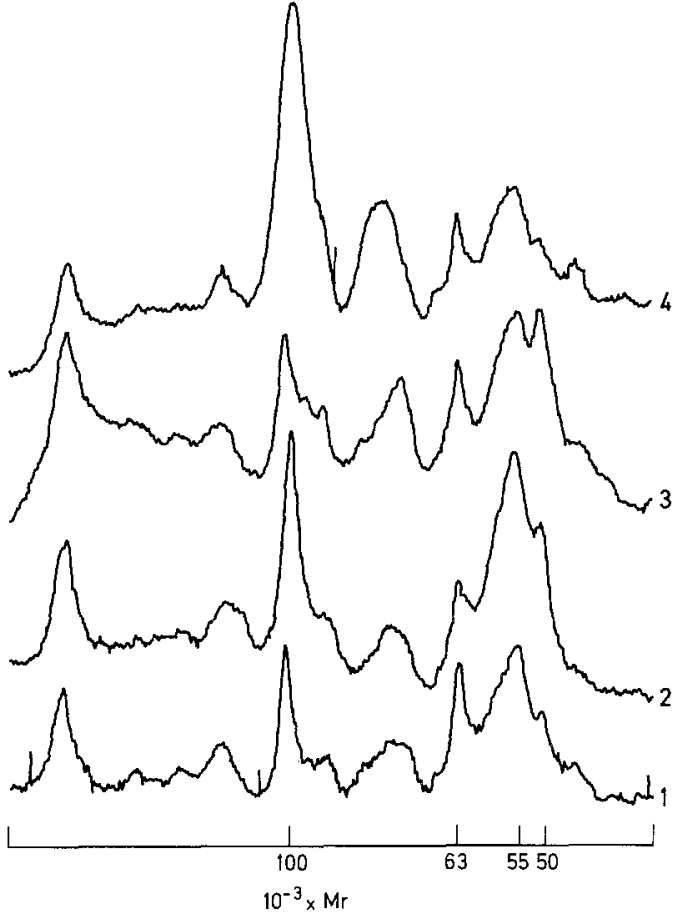

Fig. 2. Spermine-enhanced protein phosphorylation in mouse islet cytosol. Comparison with $\mathrm{Ca}^{2+}$ and cyclic AMP. The experimental conditions were the same as in Figure 1. Additions were made as follows: (1) none, (2) spermine ( $3 \mathrm{mmol} / 1$ ), (3) cyclic AMP ( 5 mol/1), (4) $\mathrm{Ca}^{2+}(0.1 \mathrm{mmol} / 1)$. EGTA $(1 \mathrm{mmol} / \mathrm{l})$ was included in all cases. $1.1 \mathrm{mmol} / 1$ of $\mathrm{CaCl}_{2}$ was added to obtain a free $\mathrm{Ca}^{2}$ concentration of $0.1 \mathrm{mmol} / \mathrm{l}$. The amount of protein applied to each well was $10 \mu \mathrm{g}$. The Figure shows densitometric traces of the autoradiogram

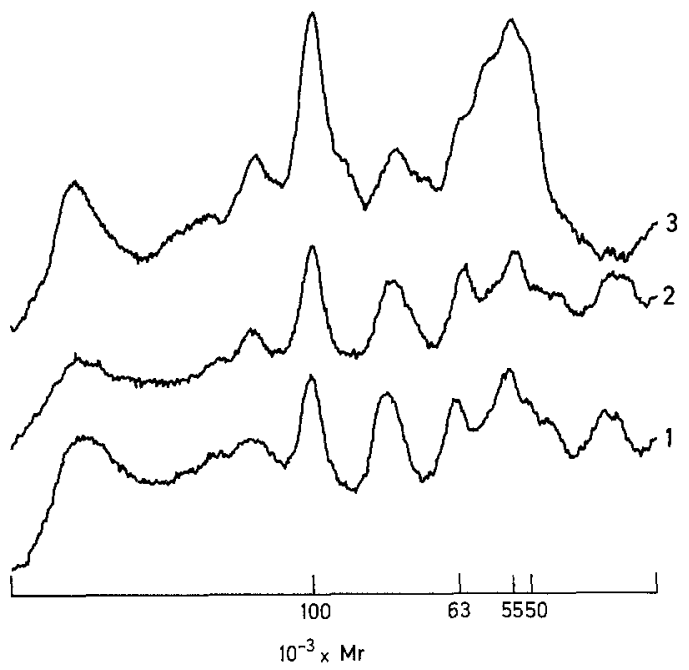

Fig. 3. Effect of cyclic AMP-dependent protein kinase inhibitor on spermine-enhanced protein phosphorylation. The experimental conditions were the same as in Figure 1. Additions: (1) cyclic AMP-dependent protein kinase inhibitor (PKI, $2000 \mathrm{U} / \mathrm{ml}$ ), (2) cyclic AMP $(5 \mu \mathrm{mol} / \mathrm{l})+\mathrm{PKI} \quad(2000 \mathrm{U} / \mathrm{ml})$, (3) spermine $(3 \mathrm{mmol} / 1)+\mathrm{PKI}$ $(2000 \mathrm{U} / \mathrm{ml})$. EGTA $(1 \mathrm{mmol} / \mathrm{l})$ was included in all cases. The amount of protein applied to each well as $10 \mu \mathrm{g}$. The Figure shows densitometric traces of the autoradiogram

protein kinase inhibitor and trifluoperazine were investigated. Cyclic AMP-dependent protein kinase inhibitor inhibited protein phosphorylation in the presence of cy- clic AMP, but could not prevent spermine-enhanced phosphorylation (Fig.3). In addition, trifluoperazine, which abolished the $\mathrm{Ca}^{2}$-calmodulin-dependent phosphorylation of the Mr 100000 protein, could not prevent spermine-enhanced protein phosphorylation in the cytosol (Fig. 4).

Since polyamine-enhanced phosphorylation is characteristic of protein kinase activity, with the capacity to utilize both GTP and ATP as phosphate donors [8], the effects of spermine on endogenous phosphorylation using $\left[\gamma_{-}{ }^{32} \mathrm{P}\right] \mathrm{GTP}$ as a phosphate donor was investigated. The patterns of both control and spermine-stimulated protein phosphorylation were found to be identical whether $\left[\gamma^{32} \mathrm{P}\right] \mathrm{GTP}$ or $\left[\gamma^{32} \mathrm{P}\right] \mathrm{ATP}$ was used as substrate (Fig. 5).

Heparin has been shown to be a potent and specific inhibitor of casein kinase II [8]. Heparin $(15 \mu \mathrm{g} / \mathrm{ml})$ inhibited ${ }^{32} \mathrm{P}$ incorporation in the $\mathrm{Mr} 50000,55000$ and 100000 proteins observable in controls. Heparin $(15 \mu \mathrm{g} / \mathrm{ml})$ could not, however, prevent phosphorylation of these proteins in the presence of spermine ( $3 \mathrm{mmol} / \mathrm{l}$ ), presumably due to complex formation between spermine and heparin (results not shown).

\section{Discussion}

The results demonstrate the presence in mouse pancreatic islets of a polyamine-enhanced protein kinase activity most likely corresponding to the casein kinase II category as reviewed by Hathaway and Traugh [8] and Cochet and Chambaz [12]. Thus, both spermidine and spermine as well as lysine-rich histone and polylysine stimulated phosphorylation and the kinase was able to use both GTP and ATP as phosphate donors, a unique ability of this kinase.

Although the regulatory mechanism and the physiological implications of casein kinase II remain largely unknown, several potential substrates of this class of enzymes, including ornithine decarboxylase [13], troponin $\mathrm{T}$ [14], glycogen synthase [15, 16], acetyl CoA carboxylase [17] and the regulatory subunit of type II cyclic AMP-dependent protein kinase [18] have been identified. Though phosphorylated, these substrates exhibit no remarkable variation in their activity; it seems to be a recurrent property of casein kinase II to mediate silent phosphorylations, i. e. phosphorylation of enzymes at sites that do not directly influence the catalytic activity. Recently, however, it has been shown that the apparently silent phosphorylation of glycogen synthase by casein kinase II enhances the subsequent effect of glycogen synthase kinase 3 which promotes a decrease of activity [16].

The stimulatory effect of polyamines on casein kinase II activity has been shown to vary with the protein substrates employed, and the amount of polyamines giving maximum stimulation also varies with the amount of substrates used [7]. Therefore, polyamines 


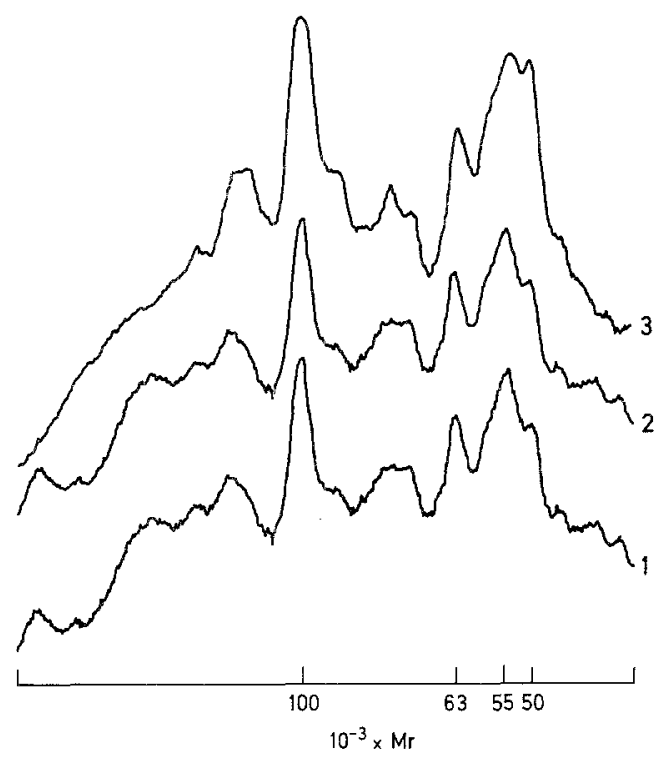

Fig.4. Effect of trifluoperazine on spermine-enhanced protein phosphorylation. The experimental conditions were the same as in Figure 1. Additions: (1) trifluoperazine (TFP, $100 \mu \mathrm{mol} / \mathrm{l})$, (2) $\mathrm{Ca}^{2}+(0.1 \mathrm{mmol} / 1)+$ TFP $(100 \mu \mathrm{mol} / 1),(3)$ spermine $(3 \mathrm{mmol} / \mathrm{l})+\mathrm{TFP}$ $(100 \mu \mathrm{mol} / \mathrm{l})$. EGTA $(1 \mathrm{mmol} / 1)$ was included in all cases. $1.1 \mathrm{mmol} / 1$ of $\mathrm{CaCl}_{2}$ was added to obtain a free $\mathrm{Ca}^{2+}$ concentration of $0.1 \mathrm{mmol} /$ 1. The amount of protein applied to each well was $10 \mu \mathrm{g}$. The Figure shows densitometric traces of the autoradiogram

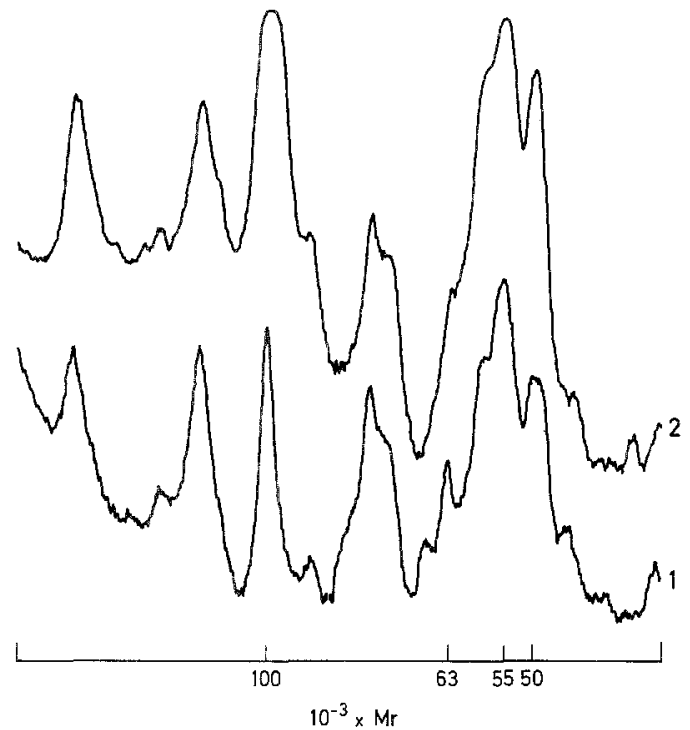

Fig.5. Effect of GTP on spermine-enhanced protein phosphorylation in mouse islet cytosol. The experimental conditions were the same as in Figure 1 except that $\left[\gamma-{ }^{32}\right.$ P]GTP $(10 \mu \mathrm{mol} / 1)$ was used as phosphate donor. Additions: (1) none, (2) spermine ( $3 \mathrm{mmol} / \mathrm{l})$. EGTA ( $1 \mathrm{mmol} /$ l) was included in all cases. The amount of protein applied to each well was $10 \mu \mathrm{g}$. The Figure shows densitometric traces of the autoradiogram

appear to augment protein phosphorylation via substrate interaction rather than via enzyme interaction $[7$, 12].

The major endogenous substrates for casein kinase II in islet cytosol were 3 proteins with $\mathrm{Mr}$ values of 50000,55000 and 100000 . Several other substrate pro- teins, including a $\mathrm{Mr} 63000$ protein, were also present in several preparations of islet cytosol (Fig. 1). However, the phosphorylation of the Mr 63000 protein was not always observable. The reason for this variation among different preparations of islet cytosol is unknown.

It is possible that the Mr 55000 protein phosphorylated by both cyclic AMP-dependent protein kinase and casein kinase II in islet cytosol is identical to the regulatory subunit of type II cyclic AMP-dependent protein kinase (Mr 56000), which previously has been shown to be a substrate for both the catalytic subunit of cyclic AMP-dependent protein kinase and casein kinase II [18].

Phosphorylation of a $\mathrm{Mr} 100000$ protein by $\mathrm{Ca}^{2+}$-calmodulin-dependent protein kinase is of widespread tissue distribution [19], and this protein is a major endogenous substrate for $\mathrm{Ca}^{2+}$-calmodulin-dependent protein kinase in cellfree extracts of pancreatic islets [2] and insulinoma cells [20]. The identity and function of this protein is not known. It remains to be established whether this protein is identical to the $\mathrm{Mr}$ 100000 protein phosphorylated by casein kinase II in islet cytosol.

We have recently found that mouse islets contain $0.3-0.5 \mathrm{mmol} / 1$ of putrescine, $3.9-5.9 \mathrm{mmol} / 1$ of spermidine and $1.2-1.9 \mathrm{mmol} / 1$ of spermine [5]. Thus, the concentrations of spermidine and spermine in islets are high enough for them to cause activation of casein kinase II. The total cellular content of polyamines does not seem to be regulated by insulin secretagoges, i.e. glucose, the phorbol ester 12-0-tetradecanoylphorbol13-acetate or the sulphonyl urea glibenclamide [5]. However, so far the intracellular distribution of polyamines in islet cells is not known; it is possible that $\mathrm{Ca}^{2+}$-influx, which seems to prevent polyamine-inhibition of insulin secretion [5], leads to a redistribution or sequestration of polyamines with marked effects on polyamine-mediated casein kinase II activity.

In conclusion, the presence of substantial amounts of the polyamines putrescine, spermidine and spermine in islets [5], their inhibitory effect on protein kinase $C$ in islet [5], as well as the present observations of a cytosolic polyamine-enhanced casein kinase II activity in islets suggest that polyamines may have an important role in regulation of protein phosphorylation in pancreatic islets.

Acknowledgements. This work was supported by financial aid from the Danish Medical Research Council (grant no 12-5693), NOVO Foundation, Nordic Insulin Foundation, P. Carl Petersens Foundation, Dr. med. Erik Garde and Elisabeth Garde's legat and the Danish Diabetic Association. The skilful technical assistance of Mr. V. Larsen is highly appreciated.

\section{References}

1. Harrison DE, Ashcroft SJH (1982) Effects of $\mathrm{Ca}^{2+}$, calmodulin and cyclic AMP on the phosphorylation of endogenous proteins by homogenates of rat islets of Langerhans. Biochim Biophys Acta $714: 313-319$ 
2. Thams P, Capito K, Hedeskov CJ (1984) Endogenous substrate proteins for $\mathrm{Ca}^{2+}$-calmodulin-dependent, $\mathrm{Ca}^{2+}$-phospholipiddependent and cyclic AMP-dependent protein kinases in mouse pancreatic islets. Biochem J 221: 247-253

3. Christie MR, Ashcroft SJH (1985) Substrates for cyclic AMP-dependent protein kinase in islets of Langerhans. Studies with forskolin and catalytic subunit. Biochem J 227: 727-736

4. Harrison DE, Ashcroft SJH, Christie MR, Lord JM (1984) Protein phosphorylation in the pancreatic B-cell. Experientia 40: 1075-1084

5. Thams P, Capito K, Hedeskov CJ (1986) An inhibitory role for polyamines in protein kinase $\mathrm{C}$ activation and insulin secretion in mouse pancreatic islets. Biochem $\mathbf{J} 237: 131-138$

6. Mäenpää PH (1977) Effects of polyamines and polyanions on a cyclic nucleotide-independent and a cyclic AMP-dependent protein kinase. Biochim Biophys Acta 498: 294-305

7. Yamamoto M, Criss WE, Takai Y, Yamamura H, Nishizuka Y. (1979) A hepatic soluble cyclic nucleotide-independent protein kinase. Stimulation by basic polypeptides. J Biol Chem 254: 5049-5052

8. Hathaway GH, Traugh JA (1982) Casein kinases - multipotential protein kinases. Curr Top Cell Regul 21: 101-127

9. Qi D-F, Schatzman RC, Mazzei GJ, Turner RS, Raynor RZ, Liao S, Kuo JF (1983) Polyamines inhibit phospholipid-sensitive and calmodulin-sensitive $\mathrm{Ca}^{2+}$-dependent protein kinases. Biochem J 213: 281-288

10. Coll-Garcia E, Gill JR (1969) Insulin release by isolated pancreatic islets of the mouse incubated in vitro. Diabetologia 5: 61-66

11. Laemmli UK (1970) Cleavage of structural proteins during the assembly of the head of the bacteriophage T4. Nature 227:680-685

12. Cochet C, Chambaz EM (1983) Polyamine-mediated protein phosphorylations: A possible target for intracellular polyamine action. Mol Cell Endocrinol 30: 247-266

13. Meggio F, Flagmini F, Caldarera CM, Guarnieri C, Pinna LA (1984) Phosphorylation of rat heart ornithine decarboxylase by type-2 casein kinase. Biochem Biophys Res Commun 122: 997-1004
14. Villar-Palasi C, Kuman A (1981) Purification and properties of dog cardiac troponin T kinase. J Biol Chem 256:7409-7415

15. Cohen P, Yellowlees D, Aitken A, Donella-Deana A, Hemmings BA, Parker PJ (1982) Separation and characterisation of glycogen synthase kinase 3, glycogen synthase kinase 4 and glycogen synthase kinase 5 from rabbit skeletal muscle. Eur J Biochem 124: 21-35

16. Camici A, Ahamad Z, De Paoli-Roach AA, Roach PJ (1984) Phosphorylation of rabbit liver glycogen synthase by multiple protein kinases. J Biol Chem 259: 2466-2473

17. Tipper JP, Bacon GW, Witters LA (1983) Phosphorylation of acetyl-coenzyme A carboxylase by casein kinase I and casein kinase II. Arch Biochem Biophys 227: 386-396

18. Carmichael DE, Geahlen RL, Allen SM, Krebs EG (1982) Type II regulatory subunit of CAMP-dependent protein kinase. Phosphorylation by casein kinase II at a site that is also phosphorylated in vivo. J Biol Chem 257: 10440-10445

19. Nairn AC, Bhagat B, Palfrey HC (1985) Identification of calmodulin-dependent protein kinase III and its major Mr 100000 substrate in mammalian tissues. Proc Natl Acad Sci USA 82: 7939-7943

20. Schubart UK, Erlichman J, Fleischer N (1980) The role of calmodulin in the regulation of protein phosphorylation and insulin release in hamster insulinoma cells. J Biol Chem 255: 4120-4124

Received: 25 June 1986

and in revised form: 4 November 1986

Dr. Peter Thams

Department of Biochemistry A

University of Copenhagen

3C Blegdamsvej

DK-2200 Copenhagen N

Denmark 